\title{
Three Medals for Switzerland at the 36th International Chemistry Olympiad 2004
}

\author{
Dustin Hofstetter*
}

Abstract: At the 2004 Chemistry Olympiad in Kiel, the Swiss students won three bronze medals.

Keywords: International Chemistry Olympiad · Swiss students

The $36^{\text {th }}$ International Chemistry Olympiads were held in Kiel, July $18^{\text {th }}-27^{\text {th }}$, 2004. They were supposed to be held in Switzerland, as officially announced in 2000 in Copenhagen. Two years later in Groningen (NL), due mostly to personality clashes, we unfortunately had to announce that we could not fulfill our task. Quite heroically, Germany accepted the task. Of course, they did have some experience, as the Chemistry Olympiads have already been organized three times in Germany. Everybody knows how good the Germans are at organizing, and we were quite surprised to see that at one point the organization did not work perfectly: the weather! It was rather cold and rainy. Fortunately the students did have the opportunity of walking in the Watte mud at the North Sea (233 students with what looked like black socks) and swimming in the lake quite near their living quarters, some $30 \mathrm{~km}$ from Kiel, in a formation centre. Meanwhile the mentors were discussing the problems, and translating them, in Kiel. The candidates lived in two hotels within a ten minutes walk: one a little more luxurious with indoor pool, the other at the sea-side, with a nice view of the bay, sailing boats, big liners, and a very pleasant terrace.

The four members of the Swiss team were:

- Silvan Birbaum, 6340 Baar, from Kantonsschule Zug,

- Arnaud Haemmerlé, 1227 Carouge, from Collège de Staël, Carouge,

- Jonas Haener, 3043 Uettlingen, from Gymnasium Bern-Neufeld,

- Kathrin Székely, 8032 Zürich, from Gymnasium Hohe Promenade, Zürich.

The two mentors were Blenda Weibel, Gymnase de la Cité, Lausanne and Dustin Hofstetter, ETHZ.
The theoretical problems were mostly on thermodynamics with some organic chemistry, but without any spectroscopy at all. 'If I had known that Diels was from Kiel...', said the Italian head-mentor. The practical problems included an organic synthesis (with a one-hour reflux that required some organization) and of course some titrations. There were some problems with the water supply, which were quickly resolved, with a heating magnetic stirrer that did not heat, and with another student who cut himself on glassware. Nothing out of the ordinary! Due probably to the great amount of calculations, time was short and

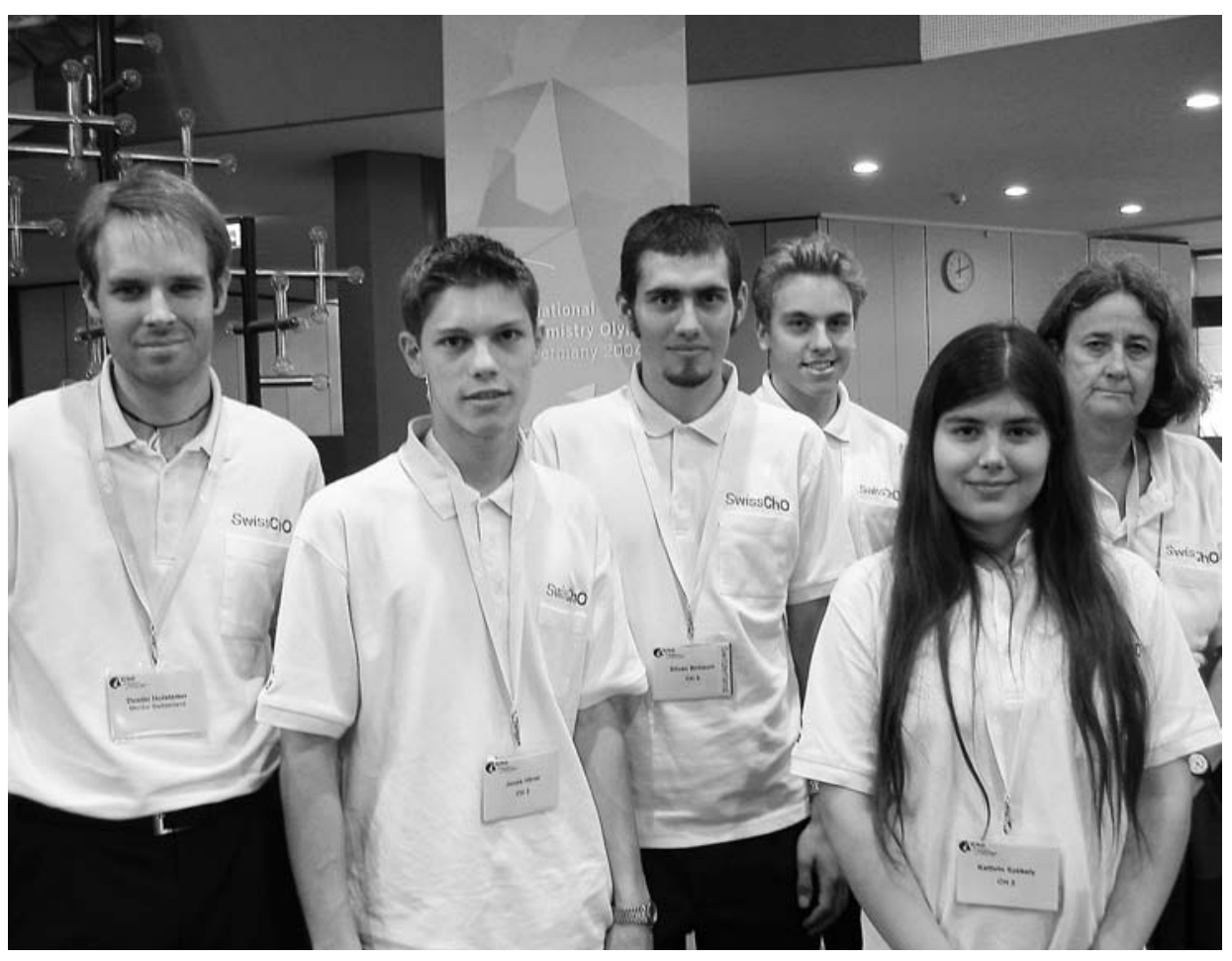

From left to right : Dustin Hofstetter (Deputy Mentor, ETHZ), Jonas Häner (Bronze, Uettlingen, BE), Silvan Birbaum (Baar ZG), Arnaud Haemmerlé (Bronze, Carouge, GE), Kathrin Székely (Bronze, Zürich, ZH), Blenda Weibel (Head Mentor, Lausanne, VD).

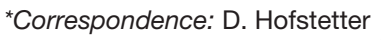
Laboratorium für Anorganische Chemie ETH Hönggerberg, $\mathrm{HCl} \mathrm{H} 212$ $\mathrm{CH}-8053$ Zürich

Tel.: +4116332852

E-Mail: dustin.hofstetter@inorg.chem.ethz.ch 
the best student 'only' got 88.4 points out of 100. He was a Russian, Aleksey Zelfman. The other gold medalists were of course from China (140'000 participants in the first elimination round!), but also from 'old Europe', Japan (participating for the 2nd time), Azerbaijan, Australia, India, Korea, Chinese Taipei, etc. Switzerland won three bronze medals, which was in fact more than we hoped for: A. Haemmerlé, J. Haener, and K. Székely.

Back home one student mailed me that he feels a little bit lost, being more or less alone after having spent ten days with 232 students from 61 countries, speaking at least three different languages...

Next year, the Olympiad will be held in Chinese Taipei, then Korea 2006, Russia or Lithuania 2007, Hungary 2008, UK 2009. When will Switzerland manage to get organized?

The Swiss Team thanks all their supporters, especially the KGF (Kontaktgruppe für Forschung) and to the BBW (Bundesamt für Bildung und Wissenschaft).

Excerpts of some Olympic tasks will give a taste of the difficulties to be solved.

\section{Problem 1. Solid State Chemistry}

Attempts to reduce $\mathrm{CaCl}_{2}$ to $\mathrm{CaCl}$ have been made with (a) calcium, (b) hydrogen, (c) carbon.

1.1. Give the corresponding equations that could potentially lead to the formation of $\mathrm{CaCl}$.

After an attempt to reduce $\mathrm{CaCl}_{2}$ with $\mathrm{Ca}$ and the stoichiometric ratio $1: 1$, an inhomogeneous grey substance is obtained, made of silvery metallic particles and colorless crystals.

1.2. What substances are the metallic particles and the colorless crystals?

In an attempt to reduce $\mathrm{CaCl}_{2}$ with elemental hydrogen a white product is formed containing $52.36 \mathrm{~m} / \mathrm{m} \%$ of calcium and $46.32 \mathrm{~m} / \mathrm{m} \%$ of chlorine.

1.3. Determine the empirical formula of the compound formed!

\section{Answers:}

1.1. (a) $\mathrm{CaCl}_{2}+\mathrm{Ca} \rightarrow 2 \mathrm{CaCl}$,

(b) $2 \mathrm{CaCl}_{2}+\mathrm{H}_{2} \rightarrow 2 \mathrm{CaCl}+2 \mathrm{HCl}$,

(c) $4 \mathrm{CaCl}_{2}+\mathrm{C} \rightarrow 4 \mathrm{CaCl}+\mathrm{CCl}_{4}$.

1.2 $\mathrm{Ca}$ and $\mathrm{CaCl}_{2}$

1.3. $\mathrm{CaClH}$.

\section{Problem 2. Thermodynamics}

A swimming pool is heated by natural gas.

2.1. Write down the chemical Eqns. for the complete combustion of the main components of natural gas, methane, and ethane. Assume that nitrogen is inert under the chosen conditions.

2.2. Calculate the reaction enthalpy, the reaction entropy, and the Gibbs energy under standard conditions (101'300 $\mathrm{Pa}, 25.0{ }^{\circ} \mathrm{C}$ ) for the combustion of methane and ethane according to the Eqns. above assuming that all products are gaseous. $\Delta \mathrm{H}^{0}$ (methane $)=-802.5$ $\mathrm{kJ} \mathrm{mol}^{-1}, \Delta \mathrm{S}^{0}$ (methane) $=-5.3 \mathrm{~J}$ $\mathrm{mol}^{-1} \mathrm{~K}^{-1}, \Delta \mathrm{G}^{0}$ (methane) $=-800.9 \mathrm{~kJ}-$ $\mathrm{mol}^{-1}, \Delta \mathrm{H}^{0}$ (ethane) $=-2856.8 \mathrm{~kJ}-$ $\mathrm{mol}^{-1}, \quad \Delta \mathrm{S}^{0}$ (ethane) $=+93.3 \mathrm{~J}$ $\mathrm{mol}^{-1} \mathrm{~K}^{-1}, \Delta \mathrm{G}^{0}$ (ethane $)=-2884.6 \mathrm{~kJ}$ $\mathrm{mol}^{-1}$.

\section{Answers:}

2.1. (a) $\mathrm{CH}_{4}+2 \mathrm{O}_{2} \rightarrow \mathrm{CO}_{2}+2 \mathrm{H}_{2} \mathrm{O}$,

(b) $2 \mathrm{C}_{2} \mathrm{H}_{6}+7 \mathrm{O}_{2} \rightarrow 4 \mathrm{CO}_{2}+6 \mathrm{H}_{2} \mathrm{O}$

\section{Problem 3. Catalysis}

The exhaust gases of an Otto engine contain carbon monoxide, nitrogen monoxide and unburned hydrocarbons, such as octane. These gases are converted to carbon dioxide, nitrogen and water in a catalytic converter. Complete the chemical equations for the reactions of the main pollutants in the catalyst.

\section{Answers:}

$2 \mathrm{CO}+\mathrm{O}_{2} \rightarrow 2 \mathrm{CO}_{2}$,

$2 \mathrm{NO}+2 \mathrm{CO} \rightarrow \mathrm{N}_{2}+2 \mathrm{CO}_{2}$,

$2 \mathrm{C}_{8} \mathrm{H}_{18}+25 \mathrm{O}_{2} \rightarrow 16 \mathrm{CO}_{2}+18 \mathrm{H}_{2} \mathrm{O}$.

More problems can be found at http://www.icho.de, following the link 'chemistry':

Received: October 8, 2004 